\title{
Komparasi kepemimpinan pendidikan di Indonesia dan Malaysia dalam upaya peningkatan mutu pendidikan
}

\author{
Karine Rizkita, Achmad Supriyanto * \\ Fakultas Ilmu Pendidikan, Universitas Negeri Malang. \\ Jl. Cakrawala No. 5, Sumbersari, Lowokwaru, Malang, Jawa Timur 65145, Indonesia. \\ * Corresponding Author. E-mail: a.supriyanto.fip@um.ac.id
}

\section{ARTICLE INFO \\ Article History \\ Received: \\ 11 June 2020; \\ Revised: \\ 27 August 2020; \\ Accepted: \\ 29 August 2020 \\ Available online: \\ 25 September 2020}

\section{Keywords}

Kepala sekolah;

Pendidikan;

Mutu sekolah;

Leadership;

Education;

Quality of school

\begin{abstract}
Penelitian ini bertujuan untuk memahami: 1.) Essensi pendidikan yang ada di Malaysia dan Indonesia; dan 2.) Peran kepemimpinan kepala sekolah di Malaysia dan Indonesia. Penelitian ini menggunakan penelitian kualitatif dengan teknik pengumpulan data menggunakan teknik studi literatur dengan harapan dapat memberikan penjelasan secara komprehensif terkait kualitas mutu pendidikan di negara berkembang. Hasil penelitian ini adalah 1.) Essensi pendidikan yang ada di Malaysia dan Indonesia; dan 2.) Peran kepemimpinan kepala sekolah di Malaysia dan Indonesia. Essensi pendidikan baik di Malaysia atau di Indonesia hampir sama yaitu untuk mengoptimalkan kemampuan peserta didik dalam ranah pengetahuan, sikap, dan keterampilan. Malaysia dalam pengejawantahkan tentang essensi pendidikan lebih fokus dalam mengoptimalkan keterampilan peserta didik dengan kata lain peran guru sebagai pendidik di Malaysia sangat mempengaruhi keberlangsungan pedidikan. Peran yang dilakukan kepala sekolah yang ada di Indonesia dalam kaitannya untuk meningkatkan mutu sekolah yaitu dengan cara membentuk tim peningkatan mutu, melakukan perbaikan secara berkelanjutan dengan cara berkomunikasi dan meneruskannya kepada seluruh anggota yang ada dilembaga pendidikan, dan menciptakan suasana tempat bekerja yang nyaman. Sedangkan peran kepemimpinan kepala sekolah yang ada di Malaysia diimplementasikan dengan cara kepala sekolah dapat mewujudkan visi dan misi sekolah, fokus dalam pengelolaan proses belajar mengajar dengan tujuan meningkatkan peringkat sekolah, dan komitmen dalam menciptakan kondisi atau lingkungan belajar yang positif sambil mendayagunakan seluruh warga sekolah dengan pendekatan yang ramah dan terbuka.
\end{abstract}

This study aims to understand 1.) The essence of education in Malaysia and Indonesia; and 2.) The role of the principal's leadership in Malaysia and Indonesia. This study uses qualitative research with data collection techniques using literature study techniques in the hope that it can provide a comprehensive explanation related to the quality of education in developing countries. The results of this study are 1.) The essence of education in Malaysia and Indonesia; and 2.) The role of the principal's leadership in Malaysia and Indonesia. The essence of education both in Malaysia or Indonesia is almost the same, namely to optimize the ability of students in the realm of knowledge, attitudes, and skills. The Malaysian state in the embodiment of the essence of education is more focused on optimizing the skills of students, in other words, the role of teachers as educators in Malaysia greatly influences the sustainability of education. The role of the principal in the country of Indonesia in relation to improving the quality of schools is by forming a quality improvement team, make improvements on an ongoing basis by communicating and forwarding it to all existing members of the educational institution, and create a comfortable work environment. Whereas the principal's leadership role in Malaysia is implemented in a way that the principal can embody the vision and mission of the school, focus on managing teaching and learning processes with the aim of improving school rankings, and commitment to creating positive learning conditions or environments while empowering all school residents with a friendly and open approach.

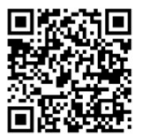

This is an open access article under the $\underline{\mathrm{CC}-\mathrm{BY}-\mathrm{SA}}$ license.

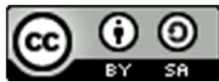

How to cite:

Rizkita, K., \& Supriyanto, A. (2020). Komparasi kepemimpinan pendidikan di Indonesia dan Malaysia dalam upaya peningkatan mutu pendidikan. Jurnal Akuntabilitas Manajemen Pendidikan, 8(2), 155-164. doi:

https://doi.org/10.21831/jamp.v8i1.32362 


\section{PENDAHULUAN}

Sekolah merupakan wadah dari lembaga pendidikan yang bertugas untuk melaksanakan aktivitas baik itu belajar ataupun pembelajaran supaya mampu mengoptimalkan daya serap, baik yang menyangkut aspek pengetahuan, sikap ataupun keterampilan. Ranah pengetahuan dapat diartikan sebagai sebuah kemampuan untuk berpikir, logika, ataupun sebuah kemampuan untuk dapat memiliki wawasan pengetahuan bagi peserta didik. Ranah sikap sendiri dapat diartikan sebagai ranah kepribadian. Peserta didik diharapkan memiliki kepribadian yang sesuai dengan norma-norma yang ada serta memiliki budi pekerti yang luhur, sedangkan ranah keterampilan adalah sebuah ranah dimana peserta didik dapat memaksimalkan softskill nya, ataupun ranah penyelarasan aktivitas peserta didik untuk dapat mempersiapkan dirinya di masa depan. Pendapat tersebut juga selaras dengan pendapat Ahmadi (2015) bahwa esensi pendidikan merupakan penyelarasan dan pengembangan kemampuan bersikap budi pekerti luhur, berpikir, serta pengembangan softskill mereka guna mempersiapkan masa depannya.

Fungsi sekolah saat ini juga semakin kompleks dan rumit karena digunakan untuk mempersiapkan peserta didik supaya memiliki kualitas yaitu peserta didik yang berkarakter, cerdas, dan kompetitif. Sekolah sangat dibutuhkan peserta didik untuk memperoleh pendidikan, meskipun pendidikan tidak hanya berasal dari pendidikan formal saja hanya saja sebagian besar peserta didik memperoleh sebuah pendidikan dari sekolah. Pendidikan sangat dibutuhkan oleh manusia. Dengan pendidikan dapat menciptakan manusia yang bermutu sehingga dapat bersama-sama dengan manusia yang lain untuk dapat menciptakan pendidikan yang baik yang lebih baik lagi.

Sekolah juga merupakan wadah sebagai agen perubahan (agent of change) yang memiliki peran dan tugas untuk dapat mencerdaskan dan melatih peserta didik supaya peserta didik mampu untuk dapat memecahkan berbagai permasalahan. Sekolah juga sebagai wadah dimana para peserta didik menimba ilmu dan pengetahuan. Oleh sebab itu, sekolah memiliki tanggung jawab yang besar untuk dapat melakukan transformasi secara terus menerus dan juga berkelanjutan untuk dapat memenuhi kebutuhan pelanggan baik primer, sekunder, ataupun tersier. Hal tersebut juga selaras dengan pendapat Hermawan (2018) bahwa sekolah sebagai satuan pendidikan yang berfungsi melaksanakan pendidikan dalam program-programnya tidak hanya sekedar program tersebut telah berjalan atau tidak, melainkan harus dapat memenuhi harapan pelanggan baik itu pelanggan primer, sekunder, dan tersier atau bahkan memenuhi harapan pemangku kepentingan. Dari sinilah peran seorang kepala sekolah sebagai manajer senior yang memimpin sekolah untuk mencapai tujuan dan impian sekolah sesuai dengan visi dan misi demi meningkatkan mutu sekolah.

Kepala sekolah selaku top manajer atau manajer senior, memiliki tugas untuk menjalankan tugas-tugas administratif dan mengkoordinasikan sumber daya yang ada di sekolah. Tugas adminstratif yang wajib dilaksanakan oleh manajer senior, seperti mulai dari merencanakan, mengorganisasikan, melaksanakan, dan mengevaluasi. Jika ditela'ah dan diamati peran dan kewajiban kepala sekolah sangatlah beraneka ragam, hal itulah yang menyebabkan kepala sekolah mempunyai tantangan untuk dapat melaksanakan pendidikan yang terencana dan sistematis demi dapat meningkatkan mutu dari sekolah yang sedang di pimpinnya. Upaya yang dapat dilakukan dapat diwujudkan dengan cara kepala sekolah wajib memiliki pengamatan dan prediksi yang jelas dan terarah untuk dapat meningkatkan mutu sekolah yang sedang ia pimpin. Karena sebaik apapun suatu kebijakan yang telah diputuskan oleh pemerintah masih sangat bergantung dari keuletan kepala sekolah dalam mengejawantahkan dan menginterpretasikan visi dan misi sekolah. Kemajuan sekolah dapat diperhatikan dari bagaimana seorang kepala sekolah memainkan perannya untuk dapat memanfaatkan sumber daya, sehingga dapat dimanfaatkan secara efektif dan tepat sasaran. Keberhasilan atau kegagalan sekolah sangat tergantung dari baban atau kewajiban yang dilaksanakan oleh kepala sekolah (Nasution, 2015).

Keberhasilan dan kegagalan suatu sekolah juga sangat tergantung dari bagaimana peran yang dijalankan oleh kepala sekolah untuk menciptakan suatu ide atau gagasan untuk dapat meningkatkan mutu sekolah. Kepala sekolah yang sukses dan mampu memimpin sekolah adalah kepala sekolah yang mampu menjalankan peran yang diberikan untuk tetap amanah dalam memimpin dan meningkatkan mutu sekolah. Oleh sebab itu, kepala sekolah memiliki tugas dan kewajiban yang sangat strategis dalam rangka meningkatkan mutu sekolah. Jika ditinjau dari pengertian mutu 
merupakan suatu gambaran dari sebuah organisasi atau suatu lembaga atas kualitas yang diberikan produsen kepada konsumen untuk dapat meningkatkan kepuasan dari konsumen tersebut. Artinya apabila suatu organisasi atau lembaga tersebut dapat memanajemen dengan baik, maka harus bisa memiliki hubungan yang baik pula dengan konsumennya. Dari gambaran itulah suatu organisasi atau lembaga bisa dikatakan bermutu.

Kepemimpinan yang efektif harus mampu memberi landasan untuk dapat memberikan trobosan-trobosan terbaru dalam rangka program pembelajaran; meningkatkan produktivitas seluruh sumber daya manusia yang berada dalam satu lingkungan sekolah dan juga mampu mengembangkan ide atau gagasan yang dapat berguna untuk meningkatkan mutu sekolah. Mutu sekolah juga sangat bergantung pada sistem manajemen sekolah. Sekolah yang sistem manajemennya kurang baik akan mengakibatkan mutu sekolah juga tidak baik, begitu sebaliknya jika sistem manajemen sekolahnya baik maka mutu sekolah tersebut juga akan menjadi baik.

Jadi dapat disimpulkan bahwa pemimpin seyogyanya cakap dalam menata rencana dan program kerja yang bermutu. Selain merencanakan atau menyusun program kerja sekolah juga wajib melaksanakannya secara konsisten serta melakukan pengawasan dengan secara terus menerus atau continue. Oleh karena itu, dalam menjalankan fungsi kepemimpinan, pemimpin lembaga pendidikan seperti halnya kepala sekolah sebaiknya selalu melaksanakan kepemimpinan yang bermutu, yaitu pemimpin yang memiliki visi, misi, inspirasi, keterbukaan dalam komunikasi, mengembangkan tim kerja, memenuhi harapan pelanggan, melakukan perbaikan secara terus menerus, dan menunjukkan komitmennya secara berkualitas.

\section{METODE}

Metode penelitian ini menggunakan penelitian kualitatif. Sasaran penelitian berguna untuk menganalisis dan membandingkan kepemimpinan kepala sekolah yang terdapat di Indonesia dan di Malaysia. Penelitian ini dirancang dengan teknik pengumpulan data berupa studi literatur atau studi kepustakaan. Artikel ini disusun dengan menggunakan kajian literatur yang ditelaah secara kritis dan komprehensif. Berkaitan dengan berbagai sumber yang ditelaah dan ditinjau oleh tim penyusun, menggunakan dua sumber rujukan, yakni sumber rujukan primer berupa karya ilmiah terdahulu dan artikel ilmiah yang telah terpublikasi dengan index yang mempunyai kredibilitas tinggi dan sumber rujukan sekunder berupa text book.

Kajian literatur dapat dijadikan tool untuk menyusun kerangka sebuah penyelesaian ketika menghadapi sebuah permasalahan. Metode kajian literatur sendiri juga dapat digunakan sebagai landasan untuk dapat menemukan sebuah teori baru. Data penelitian ini diperoleh melalui studi literatur yang berkaitan dengan peningkatan mutu di suatu negara berkembang. Penelitian ini dilakukan hanya berdasarkan dari suatu hasil karya tertulis, baik itu hasil dari suatu penelitian yang telah terpublikasi maupun yang belum terpublikasikan. Penelitian studi literatur ini tidak mengharuskan seorang peneliti turun dan bertemu langsung dengan responden di lapangan. Data yang diperlukan dalam penelitian diperoleh dari literasi atau bacaan. Zed (2014) menyampaikan bahwa pada penelitian literasi, dan penelusuran pustaka tidak hanya untuk mengawali dalam rangka mempersiapkan konsep penelitian akan tetapi juga bisa digunakan untuk memanfaatkan sumber-sumber bacaan yang ada di perpustakaan online ataupun offline untuk memperoleh data penelitian. Persiapan penelitian studi literatur sama seperti penelitian kualitatif lainnya hanya saja ada perbedaan pada sumber dan metode pengumpulan datanya.

Kajian literatur merupakan teknik yang digunakan oleh seorang peneliti dalam melakukan penelitian ini. Penelitian kajian literatur dapat dilakukan dengan cara memanfaatkan buku referensi atau hasil penelitian sebelumnya yang mungkin satu tema dengan fokus yang sedang dilakukan oleh peneliti (Ulfatin, 2013). Kajian literatur dapat mengambil dari berbagai sumber seperti: buku, jurnal, e-book, majalah, koran, dan peraturan atau kebijakan. Studi komparasi adalah jenis ilmu untuk membandingkan persamaan dan perbedaan dua atau lebih objek yang diteliti untuk dapat menemukan suatu kerangka pemikiran baru. Selaras dengan pendapat Pfeffer (2015) bahwa studi komparasi merupakan sebuah konsep untuk mengukur kualitas dan kesetaraan yang dapat digunakan untuk mempelajari hubungan antar hasil-hasil yang telah di dapatkan. 


\section{HASIL DAN PEMBAHASAN}

Hasil

Dari hasil kajian literatur yang telah peneliti lakukan guna memperoleh data tentang essensi pendidikan yang ada di Malaysia dan di Indonesia dan juga peran kepemimpinan kepala sekolah yang ada di Malaysia dan Indonesia adalah sebagai berikut. Essensi pendidikan baik di Negara Malaysia atau di Negara Indonesia hampir sama yaitu untuk mengoptimalkan kemampuan peserta didik dalam ranah pengetahuan, sikap, dan keterampilan. Sedangkan di Malaysia dalam hal mewujudkan tentang essensi pendidikan lebih fokus untuk mengoptimalkan keterampilan peserta didik dengan kata lain peran guru sebagai pendidik di Malaysia sangat mempengaruhi keberlangsungan pedidikan. Oleh karena itu, dapat ditarik kesimpulan tentang essensi pendidikan merupakan usaha untuk dapat mengarah peserta didik dalam hal mengembangkan potensi pengetahuan, sikap, dan keterampilan yang ada pada diri peserta didik. Pendidikan dalam hal ini guru dan kepala sekolah memiliki tugas untuk menghasilkan generasi yang lebih, bermoral, dan beretika.

Peran yang dilakukan kepala sekolah yang ada di Indonesia dalam kaitannya untuk meningkatkan mutu sekolah yaitu dengan cara membentuk tim peningkatan mutu, melakukan perbaikan secara berkelanjutan dengan cara berkomunikasi dan meneruskannya kepada seluruh anggota yang ada dilembaga pendidikan, dan menciptakan suasana kerja yang nyaman. Selain itu, peran kepemimpinan kepala sekolah yang ada di Malaysia dapat diimplementasikan dengan cara kepala sekolah dapat mewujudkan visi dan misi sekolah, fokus dalam pengelolaan proses belajar mengajar dengan tujuan meningkatkan peringkat sekolah, dan komitmen dalam menciptakan kondisi atau lingkungan belajar yang positif sambil mendayagunakan seluruh warga sekolah dengan pendekatan yang ramah dan terbuka. Oleh karena itu, dari itu dapat ditarik benang merah bahwa peran kepala sekolah dalam hal kepemimpinan di sekolah dapat diwujudkan dengan cara guna berkomitmen untuk dapat mewujudkan visi dan misi sekolah, berkomunikasi kepada seluruh anggota sekolah yang berkaitan dengan visi dan misi sekolah, dan selalu memberikan fasilitas kepada guru maupun peserta didik untuk dapat selalu mengembangkan prestasinya baik akademik maupun non akademik.

Pembahasan

Esensi Pendidikan di Negara Berkembang

Pada dasarnya pengertian pendidikan merupakan usaha yang mengarahkan peserta didik dan menciptakan situasi dan kondisi belajar supaya dapat mengoptimalkan kemampuan yang ada pada peserta didik (Munib, 2004). Selain proses pengembangan spiritual, keagamaan, dan kepribadian, pendidikan juga sebagai proses pengembangan kecakapan seorang individu dalam ranah afektif, kognitif, dan psikomotorik (Triwiyanto, 2017). Pendapat tersebut juga senada dengan pendapat dari Ahmadi (2015) bahwa esensi pendidikan merupakan penyelarasan dan pengembangan kemampuan untuk dapat bersikap budi luhur, berpikir, serta pengembangan softskill mereka guna mempersiapkan masa depannya. Pendapat tersebut juga didukung oleh pendapat Mudyahardjo (2012) bahwa pendidikan berfungsi memajukan sebuah bangsa, negara, dan masyarakatnya agar dapat bersaing secara global, baik dibidang ekonomi, pemerintahan, dan pelayanan pada masyarakatnya.

Dapat ditarik kesimpulan bahwa pendidikan merupakan suatu upaya terencana dan terstruktur yang dilaksanakan untuk dapat mengoptimalkan kemampuan peserta didik. Kemampuan yang dimiliki peserta didik tentu beraneka ragam, dan itulah merupakan tugas dari seorang guru untuk dapat mengamati dan mempertajam kemampuan yang telah dimiliki oleh peserta didiknya, sehingga peserta didik mampu menjadi insan kamil. Tugas dalam bidang pendidikan yaitu menghasilkan generasi atau penerus yang bermoral dan beretika. Sesuai dengan harapan dari pendidikan yang ada di Indonesia itu sendiri, yaitu dengan bisa menghasilkan generasi yang bermoral dan beretika, hal tersebut sesuai dengan impian masyarakat terhadap pendidikan yang ada di Indonesia tahun 2045 di antaranya yaitu aspek pendidikan karakter dan nilai-nilai multikultural. Selain itu, pendidikan juga bisa mengarahkan pada pemahaman kepribadian serta dapat mempertimbangkan aspek globalisasi (Malihah, 2015).

Tujuan pendidikan antara negara yang satu dengan negara lainnya tentu sangat berbeda. Hal tersebut disesuaikan dengan dasar dan falsafah hidup bangsa. Selaras dengan pendapat Long (2011)

Volume 8, No. 2, September 2020 
bahwa rasa perbedaan nasional itulah yang menyebabkan tujuan pendidikan dari suatu negara berbeda-beda, baik dari perbedaan tempat, orang, dan budaya. Impian pendidikan di Indonesia tahun 2045 lebih berorientasi kepada pendidikan karakter dan pemahaman kepribadian dikarenakan sistem pendidikan di Indonesia Saat ini terlalu menekankan pada ijazah formal seperti tatanan masyarakat saat ini lebih ditentukan pada ijazah yang dimiliki oleh seseorang yang ada pada tatanan masyarakat tersebut, bukan ditentukan dari kompetensi dan kualitasnya (Ridhwan, 2018). Intinya, jika memiliki ijazah formal orang tersebut dapat meraih jabatan-jabatan penting dalam suatu lingkungan birokrasi dan kedudukan penting yang ada di tengah-tengah masyarakat dengan menggunakan skala pengukuran hanya dengan suatu ijazah.

Akibatnya di Indonesia ini banyak sekali seseorang yang mengejar ijazah formal demi menduduki jabatan tertentu. Orang pergi ke sekolah atau ke kampus bukan lagi untuk mencari ilmu, tetapi untuk mencari ijazah supaya mendapatkan kedudukan. Pendidikan yang berorientasi hanya demi mendapatkan ijazah merupakan pendidikan yang menipu (Fatoni, 2014). Hakikat pendidikan yang diinginkan, yakni pendidikan yang berfokus pada pembentukan akhlak peserta didik, bukan pada perburuan ijazah formal atau pencarian gelar belaka (Kokasih, 2000). Oleh karena itu sebuah pelaksanaan proses pendidikan di negara berkembang prestasinya tidak setinggi negara maju di kancah internasional, dikarenakan hanya berorientasi penghargaan yang hanya di dasarkan prestasi dalam lingkum kelas saja (Icksan, 1985).

Malaysia merupakan suatu negara yang masyarakatnya merupakan bagian dari suku Melayu. Apabila ditinjau dari segi histori, Malaysia dahulunya juga merupakan bagian dari Indonesia. Hal ini terjadi pada abad 12 masehi pada masa kerajaan Majapahit. Indonesia merupakan negara bekas jajahan Belanda selama 350 tahun dan begitu juga Malaysia yang juga bekas jajahan Inggris. Tentunya sistem pendidikan yang berlaku di Indonesia menggunakan warisan sistem pendidikan dari Belanda, dan Malaysia tentunya juga akan menggunakan warisan sistem pendidikan dari Inggris. Sebenarnya, gaya atau model pendidikan yang terdapat di Malaysia sebagian besar sama dengan Indonesia. Malaysia juga begitu menginginkan perbaikan secara berkelanjutan dalam bidang pendidikan.

Malaysia memiliki suatu konsep, yaitu keberhasilan seorang siswa sangat bergantung dari bagaimana peran guru dan kepala sekolah. Oleh karena itu, Don (2006) mengungkapkan bahwa sekolah merupakan sarana yang paling tepat untuk mengoptimalkan keterampilan pelajar dengan kata lain bahwa peran guru sebagai pendidik di Malaysia sangat mempengaruhi keberlangsungan pedidikan yang terdapat di Malaysia, guru sebagai peran inti. Oleh karena itu, guru wajib menyusun kurikulum dan mengembangkan kurikulum dengan baik, sehingga model pendidikan yang telah ditata sedemikian rupa oleh pemerintah bisa dapat terimplementasikan (Siraj \& Ibrahim, 2016).

\section{Peran Kepemimpinan Kepala Sekolah di Malaysia dan Indonesia}

Kepemimpinan dapat diartikan sebagai usaha pemimpin supaya dapat mempengaruhi para anggotanya untuk menjalani perubahan ke arah yang lebih positif (Makawimbang, 2012). Selaras dengan pendapat Kartono (2010) pemimpin juga harus dapat mempengaruhi orang lain supaya bersedia untuk menjalankan tugas yang diberikan oleh pimpinan, demi suatu tujuan lembaga ataupun organisasi. Sudarmanto (2009) mengungkapkan kepemimpinan merupakan potensi yang wajib dimiliki oleh seorang pemimpin untuk dapat memengaruhi pegawai untuk melakukan sikap ke arah yang lebih positif. Oleh karena itu, dapat disimpulkan bahwa pengertian kepemimpinan kepala sekolah merupakan upaya kepala sekolah untuk memengaruhi semua warga sekolah supaya mau bekerja demi mencapai tujuan lembaga atau organisasi (Haryono, 2012). Masyarakat saat ini sangat menginginkan pendidikan yang bermutu dan berkualitas. Sebagian masyarakat beranggapan bahwa dengan pendidikan yang berkualitas tatanan suatu masyarakat akan lebih baik. Masyarakat sangat berharap para lulusannya dapat terampil baik dalam segi pengetahuan, keterampilan, maupun sikap.

Bagi sekolah, pembicaraan tentang mutu dan kualitas tidak akan pernah terlepas dengan yang namanya manajemen. Manajemen disini dalam artian pemimpin sekolah atau kepala sekolah. Sekolah bisa dikatakan bermutu apabila memiliki keunggulan dan daya saing serta mampu menerapkan pengelolaan manajemen. Oleh karena itu, diperlukan manajemen yang tepat dalam mengatur aktivitas pengelolaan dan pembelajaran sekolah dalam upaya meningkatkan mutu sekolah secara berkelanjutan (Ridho, 2017). Sallis (2012) juga berpendapat di dalam bukunya bahwa pengembangan mutu yang berhasil harus membutuhkan komitmen dari pihak manajemen, komitmen disini bisa 
diartikan sebagai kesadaran manajemen untuk selalu bertanggung jawab atas suatu lembaga pendidikannya dan menemukan sebuah solusi. Wujud komitmen kepala sekolah salah satunya membentuk tim peningkatan mutu (Nelda, 2016).

Melalui tim peningkatan mutu diharapkan dapat menjaga kualiitas pembelajaran dan pengelolaan sekolah (Sebastian, Camburn, \& Spillane, 2018). Komunikasi yang efektif juga sangat diperlukan antara kepala sekolah dengan tim peningkatan mutu untuk dapat dijabarkan guna menemukan strategi-strategi baru dalam menyusun rencana peningkatan mutu (Komariah \& Triana, 2006). Dapat di simpulkan, kualitas mutu sekolah dapat terus terjaga dengan adanya komitmen dari kepala sekolah supaya sekolah semakin maju dan berdaya saing dengan sekolah lainnya (Sonhadji \& Huda, 2015). Oleh karena itu, maka alangkah baiknya jika selalu diadakan perbaikan keberlanjutan dari program-program sekolah dan analisis kebutuhan untuk mendukung perbaikan program sekolah yang berkelanjutan (Zazin, 2010). Rohiat (2010) mengatakan bahwa bagian dari kegiatan sekolah yang juga memiliki nilai yang sangat penting bagi sekolahnya dapat dikatakan sebagai manajemen sekolah. Pada dasarnya usaha yang perlu dilakukan untuk dapat memajukan kualitas sekolah dalam hal pencapaian tujuan pendidikan, baik tujuan dari pemerintah pusat atau tujuan dari sekolahnya itu sendiri. Kepala sekolah dipaksa untuk bekerja secara maksimal supaya dapat menjalankan fungsinya dalam mengelola sekolah dan meraih tujuan sekolah. Kepala sekolah juga memiliki tanggung jawab dalam penyelenggaraan kegiatan pendidikan, baik itu yang bersifat administrasi, atau pembinaan pegawai.

Selaras dengan pendapat Nuryani (2013) bahwa peran kepala sekolah sebagai pemimpin lembaga pendidikan untuk dapat meningkatkan mutu tidak hanya fokus mengoptimalkan dari sisi peserta didik, namun juga harus dapat mendayagunakan dan mengoptimalkan seluruh pihak seperti peserta didik, staf, pegawai, dan komite sekolah (Syafaruddin \& Asrul, 2013). Kepala sekolah juga memiliki hubungan atau kaitan dalam menetapkan kemajuan sekolah. Oleh karena itu, kepala sekolah harus siap baik dalam kaitannya administrasi, memiliki komitmen, dan fleksibel dalam melaksanakan tugasnya. Kepala sekolah juga harus dapat memberdayakan para guru dengan cara mengikutkan para guru-guru tersebut ke dalam kegiatan pembinaan (Sallis, 2012). Oleh karena itu, kepala sekolah harus terampil untuk dapat memimpin lembaga pendidikan dan menyelesaikan permasalahan yang terdapat pada proses pembelajaran (Siahaan \& Nasution, 2006; Syafaruddin, 2010).

Kepala sekolah diharapkan dapat mengkomunikasi visi dan meneruskannya kepada seluruh anggota yang ada di lembaga pendidikan tersebut. Harapan dari pemerintah pusat maupun daerah sekolah harus mampu menwujudkan kurikulum, dan juga sekolah harus mampu memuhi kebutuhan pelang-gan baik internal dan eksternal. Sebagai akibatnya, tugas-tugas kepala sekolah semakin berkembang dan semakin kompleks. Zakaria (2015) menjelaskan beberapa peran yang wajib dilaksanakan oleh kepala sekolah dalam hal pembelajaran diimplementasikan dengan bentuk menciptakan iklim kerja yang produktif, kreatif, dan menyenangkan bagi guru. Selanjutnya, tujuan kepala sekolah sebagai pemimpin pembelajaran supaya dapat memberikan fasilitas atau layanan terhadap guru dalam mengoptimalkan prestasi belajar, kreativitas,dan inovasi. Dapat disimpulkan bahwa tugas kepala sekolah baik dalam hal memimpin atau administrasi sekolah sangat begitu saling berkaitan.

Yusup (2015) mengatakan bahwa sebagai pemimpin dalam hal pengajaran dapat diwujudkan seperti menyusun visi sekolah, berbagi jiwa kepemimpinan, menentukan keputusan pengajaran, dan memantau jalannya kegiatan belajar mengajar sudah sesuai kurikulum dan pengajaran atau belum. Peran kepala sekolah yang ada di Indonesia, kepala sekolah yang terdapat di Malaysia juga harus memiliki keterampilan-keterampilan supaya dapat memimpin suatu lembaga pendidikan. Tetapi terdapat sedikit perbedaan antar peran kepala sekolah di Indonesia dan Malaysia, di Indonesia seorang pemimpin baik itu yang sudah berpengalaman maupun yang baru berpengalaman menjadi seorang pemimpin tetap harus mematuhi peraturan, baik dari pusat maupun daerah apabila terkait dengan pemindaan jabatan kerja. Sedangkan di Malaysia kepemimpinan lebih menekankan kepada kepala sekolah yang telah profesional untuk memutuskan tetap menjadi kepala sekolah di sekolah yang saat ini dia pimpin (Tahir, Ali, \& Ahmad, 2019).

Menetapnya kepala sekolah yang telah berpengalaman tersebut berfungsi untuk dapat membantu menyelesaikan kegagalan mutu sekolah, karena Malaysia berpendapat bahwa apabila seorang kepala sekolah dipindah tugaskan ke sekolah lain dan menemui sebuah hambatan atau kegagalan, 
tetapi tidak lama kemudian kepala sekolah diganti lagi, hal tersebut bukan menghasilkan sebuah perubahan, namun menghasilkan suatu permasalahan baru. Oleh karena itu, kepala sekolah yang telah berpengalaman menyelesaikan suatu permasalahan di analisis sampai ke akar-akarnya. Sesuai dengan pendapat (Sallis, 2012) bahwa kegagalan mutu hanya bisa dibenahi dari pihak manajemen dengan cara mencari data-data terkait dengan kegagalan dan mengamati secara berkelanjutan.

Kepala sekolah juga perlu dilengkapi dengan keterampilan dalam memecahkan masalah yang sulit supaya dapat mengarahkan sekolah dan membawanya ke tingkat kualitas yang bermutu dalam semua aspek $(\mathrm{Ng}, 2016)$. Selaras dengan peran kepala sekolah yang terdapat di Indonesia, ternyata perwujudan visi dan misi sangat penting untuk keberhasilan sutau lembaga pendidikan di Malaysia, karena sebuah visi dan misi harus ditingkatkan untuk pengembangkan segala aspek-aspek yang lain (Samad, Sukor, Syah, \& Muslihah, 2014). Kepala sekolah juga wajib bisa bermain peran dalam mendukung keberhasilan sekolah dalam mencapai kinerja dengan kualitas yang terbaik (Jo, Joseph, \& Dana, 2010). Noman, Hasim, dan Abdullah (2016) menyampaikan tentang seorang pemimpin sekolah atau kepala sekolah yang sukses di Malaysia diimplementasikan dengan selalu fokus pada pengelolaan proses belajar mengajar dengan tujuan: 1.) Meningkatkan peringkat sekolah; 2.) Komitmen dalam menciptakan kondisi atau lingkungan belajar yang positif sambil mendayagunakan seluruh warga sekolah dengan pendekatan yang ramah dan terbuka; 3.) Komunikasi yang jelas tentang visi dan tujuan sekolah; dan 4.) Fokus pada prestasi akademik. Overton (2002) memberikan sebuah pesan bahwa kualitas pemimpin dimasa depan seharusnya memiliki semangat kerja yang tinggi, berintegrasi, dan memiliki etika. Secara sederhana persamaan dan perbedaan peran kepemimpinan kepala sekolah yang terdapat di Indonesia dan Malaysia dapat dilihat pada Tabel 1 dan 2 .

Tabel 1. Persamaan Peran Kepemimpinan di Indonesia dan Malaysia

\begin{tabular}{ll}
\hline \multicolumn{1}{c}{ Indonesia } & \multicolumn{1}{c}{ Malaysia } \\
\hline Komitmen kepala sekolah untuk meningkatkan & Komitmen kepala sekolah untuk dapat mewujudkan \\
mutu sekolah. & visi dan misi. \\
Berkomunikasi dengan para pegawai yang ada di & Mengkomunikasikan mengenai visi misi yang telah \\
sekolah demi kemajuan mutu sekolah. & di rumuskan. \\
Mendayagunakan baik peserta didik, guru, dan & Memberikan fasilitas kepada guru supaya dapat \\
tenaga kependidikan & mengembangkan prestasinya. \\
\hline
\end{tabular}

Tabel 2. Perbedaan Peran Kepemimpinan di Indonesia dan Malaysia

\begin{tabular}{cl}
\hline Indonesia & \multicolumn{1}{c}{ Malaysia } \\
\hline & Mempertahankan kepala sekolah yang telah \\
- & professional atau juga yang belum profesional \\
& untuk memimpin lebih lama atau sampai masa \\
& pensiun, untuk menuntaskan permasalahan yang \\
& ada di sekolah sebelum dipindah tugaskan. \\
- & Fokus dalam pengelolaan proses belajar mengajar \\
& dengan tujuan meningkatkan peringkat sekolah. \\
\hline
\end{tabular}

\section{SIMPULAN}

Hakikat atau essensi pendidikan merupakan usaha untuk dapat mengarah peserta didik mengembangkan potensi spiritual, sikap, dan pengetahuan. Pendidikan dalam hal ini adalah guru dan kepala sekolah memiliki tugas untuk menghasilkan generasi yang lebih bermoral dan beretika. Secara garis besar hakikat pendidikan baik di Malaysia ataupun di Indonesia hampir sama, yaitu bagaimana pendidikan membangun potensi pada diri peserta didik. Menempatkan kepala sekolah dan guru dalam faktor terpenting dalam sistem pendidikan, kepala sekolah selaku manajer senior dalam suatu 
sekolah yang berhak memimpin dan mengarah, dan guru bertugas menyusun kurikulum dan mengembangkan kurikulum. Peran kepala sekolah dalam rangka meningkatkan mutu pendidikan harus memfokuskan semua sumber daya yang terdapat di sekolah. Kepala sekolah yang sukses diwujudkan dengan: 1.) Selalu fokus pada pengelolaan proses belajar mengajar dengan tujuan meningkatkan peringkat dan mutu sekolah; 2.) Berkomitmen dalam menciptakan kondisi atau lingkungan belajar yang positif sambil mendayagunakan seluruh warga sekolah dengan pendekatan yang ramah dan terbuka; 3.) Berkomunikasi yang jelas tentang visi dan tujuan sekolah; dan 4.) Fokus pada prestasi akademik (Hidayati, Annurrahman, \& Radiana, 2009). Kepala sekolah diharapkan selalu pro aktif untuk meningkatkan mutu suatu lembaga pendidikan yang sedang dipimpinnya, karena tanggung jawab peningkatan mutu kuncinya berada pada kepala sekolah, meskipun seluruh anggota sekolah juga memiliki peran, namun tetaplah kepala sekolah yang memiliki peran lebih, karena selaku manajer senior di sekolah.

\section{DAFTAR PUSTAKA}

Ahmadi, R. (2015). Pengantar pendidikan. Ar-Ruzz Media.

Don, Y. D. (2006). Kepemimpinan dan pembangunan pelajar sekolah di Malaysia. Kuala Lumpur: PTS Profesional Publising.

Fatoni, S. (2014). The wisdom of Gus Dur ( $1^{\text {st }}$ ed.). Depok: Imania.

Haryono, D. (2012). Pengaruh kompetensi pedagogik dan kinerja guru terhadap mutu pembelajaran di sekolah: Penelitian survei tentang pengaruh kompetensi pedagogik dan kinerja guru SD terhadap mutu pembelajaran di Sekolah Dasar Negeri di Kabupaten Lingga Provinsi Kepulauan Riau (Unpublished doctoral Dissertation). Universitas Pendidikan Indonesia, Indonesia.

Hermawan, E. (2018). Kepemimpinan perubahan kepala sekolah dalam peningkatan mutu pendidikan. Jurnal Administrasi dan Manajemen Pendidikan, 1(3), 358-363. doi: https://doi.org/10.17977/um027v1i32018p358

Hidayati, R., Annurrahman, \& Usman, R. (2009). Kepemimpinan kepala sekolah dalam upaya meningkatkan kinerja guru di SD Negeri 67 Sungai Raya. Jurnal Pendidikan dan Pembelajaran Untan, 5(5), 1-18. Retrieved from https://media.neliti.com/media/publications/210818-kepemimpinan-kepala-sekolah-dalamupaya.pdf

Icksan, M. . (1985). Mahasiwa dan kebebasan akademik. Hamidita.

Jo, B., Joseph, B., \& Dana, Y. P. (2010). Handbook of school improvement. Thousand Oaks, CA: Corwin Press.

Kartono, K. (2010). Pemimpin dan kepemimpinan: Apakah kepemimpinan abnormal itu. Jakarta: Raja Grafindo Persada.

Kokasih, E. (2000). Hak Gus Dur untuk nyleneh ( $1^{\text {st }}$ ed.). Bandung: Pustaka Hidayah.

Komariah, A., \& Triana, C. (2006). Visionary leadership menuju sekolah efektif. Jakarta: Bumi Aksara.

Long, N. (2011). Bordering on immoral: Piracy, education, and the ethics of cross-border cooperation in the Indonesia-Malaysia-Singapore Growth Triangle. Anthropological Theory, 11(4), 441464. doi: https://doi.org/10.1177/1463499611423869

Makawimbang, J. H. (2012). Kepemimpinan pendidikan yang bermutu. Bandung: Alfabeta.

Malihah, E. (2015). An ideal Indonesian in an increasingly competitive world: Personal character and values required to realise a projected 2045 'Golden Indonesia.' Citizenship, Social and Economics Education, 14(2), 148-156. doi: https://doi.org/10.1177/2047173415597143 
Mudyahardjo, R. (2012). Pengantar pendidikan: Sebuah studi tentang dasar-dasar pendidikan pada umumnya. Rajawali Pers.

Munib, A. (2004). Pengantar ilmu pendidikan. Semarang: UPT UNNES Press.

Nasution, W. N. (2015). Kepemimpinan pendidikan di sekolah. Jurnal Tarbiyah, 22(1), 66-86. doi: http://dx.doi.org/10.30829/tar.v22i1.6

Nelda, F. (2016). Hubungan kepemimpinan kepala sekolah dengan komitmen guru dalam melaksanakan tugas di SMK N 2 Pariaman. Jurnal Bahana Manajemen Pendidikan, 4(1), 1-8. doi: https://doi.org/10.24036/bmp.v4i1.5967

Ng, A. Y. M. (2016). School leadership preparation in Malaysia: Aims, content and impact. Educational Management Administration and Leadership, 45(6), 1002-1019. doi: https://doi.org/10.1177/1741143216662922

Noman, M., Hashim, R, A., \& Abdullah, S. S. (2016). Contextual leadership practices: The case of a successful school principal in Malaysia. Educational Management Administration and Leadership, 46(3), 474-490. doi: https://doi.org/10.1177/1741143216665840

Nuryani, N. (2013). Principal leadership in improving the quality of education (A site study at SMP Negeri 3 Ungaran) (Unpublished master's thesis). Universitas Muhammadiyah Surakarta, Indonesia.

Overton, R. (2002). Leadership made simple. Singapore: Wharton Books, Pte. Ltd.

Pfeffer, F. T. (2015). Equality and quality in education. A comparative study of 19 countries. Social Science Research, 51, 350-368. doi: https://doi.org/10.1016/j.ssresearch.2014.09.004

Ridho, A. (2017). Meningkatkan mutu manajemen madrasah (Kajian minat masyarakat dan prinsip dasar manajemen lembaga pendidikan Islam). FIKROTUNA, 6(2). doi: https://doi.org/10.32806/jf.v6i2.3096

Ridhwan, D. S. (2018). Essensi pendidikan Islam dalam perspektif Abdurrahman Wahid. Istighna: Jurnal Pendidikan dan Pemikiran Islam, 1(1), 98-115. doi: https://doi.org/10.33853/istighna.vli1.19

Rohiat, R. (2010). Manajemen sekolah: Teori dasar dan praktik. Bandung: Refika Aditama.

Sallis, E. (2012). Total quality management in education. Yogyakarta: IRCISOD.

Samad, R. S. A., Sukor, M. I. R. M., Syah, D., \& Muslihah, E. (2014). Understanding the implementation of knowledge management in high-performance schools in Malaysia. SAGE Open, 4(4), 1-7. doi: https://doi.org/10.1177/2158244014561206

Sebastian, J., Camburn, E. M., \& Spillane, J. P. (2018). Portraits of principal practice: Time allocation and school principal work. Educational Administration Quarterly, 54(1), 47-84. doi: https://doi.org/https://doi.org/10.1177/0013161X17720978

Siahaan, A. W. K., \& Nasution, I. (2006). Manajemen pendidikan berbasis sekolah. Jakarta: Quantum Teaching.

Siraj, S., \& Ibrahim, M. S. (2012, October). Standard kompetensi guru Malaysia. In Prosiding Seminar Kebangsaan Majlis Dekan Pendidikan IPTS 2012, Universiti Malaya, Kuala Lumpur, Malaysia.

Sonhadji, A., \& Huda, A. (2015). Assesmen kebutuhan, pengambilan keputusan, dan perencanaan matarantai dalam manajemen pendidikan. Malang: UM Press.

Sudarmanto, S. (2009). Kinerja dan pengembangan kompetensi SDM. Teori, dimensi pengukuran, dan implementasi dalam organisasi. Yogyakarta: Pustaka Pelajar.

Syafaruddin, S. (2010). Kepemimpinan pendidikan. Jakarta: Quantum Teaching. 
164 - Jurnal Akuntabilitas Manajemen Pendidikan

Syafaruddin, S., \& Asrul, A. (2013). Kepemimpinan pendidikan kontemporer. Bandung: Cita Pustaka Media.

Tahir, L. M., Ali, M. F., \& Ahmad, J. (2019). Principals changing schools and their career options after principalship: Exploring reasons and options within Malaysian principalship. Management in Education, 33(3), 110-117. doi: https://doi.org/10.1177/0892020619836718

Triwiyanto, T. (2017). Pengantar pendidikan. Jakarta: Bumi Aksara.

Ulfatin, N. (2013). Metode penelitian kualitatif di bidang pendidikan. Malang: Bayumedia Publishing.

Yusup, M. (2015). Peran kepala sekolah sebagai pemimpin pembelajaran. Manajer Pendidikan, 9, 95-100.

Retrieved

from https://ejournal.unib.ac.id/index.php/manajerpendidikan/article/download/1103/914

Zakaria, Z. (2015). Bahan ajar: Kepala sekolah sebagai pemimpin pemelajaran. Bengkulu: Universitas Bengkulu.

Zazin, N. (2010). Kepemimpinan \& manajemen konflik: Strategi mengelola konflik dalam Inovasi organisasi dan pendidikan di madrasah atau sekolah yang unggul. Yogyakarta: Absolute Media.

Zed, M. (2014). Metode penelitian kepustakaan. Jakarta: Yayasan Obor Indonesia. 